\title{
FALSAFAH HIDUP ORANG FAKFAK \\ SATU TUNGKU TIGA BATU [TOROMIT WAR ISTERY]
}

\section{Marthinus Ngabalin}

\begin{abstract}
Athree-stone heart his partof a system ofinter-institutional cooperation in Fak-Fak Regency. Butitalso contains thehuman valuesthat lead tointer-religious relations, mutual help, care about each otherin distress and short ages without making religionas asource of conflict, orthe reason fornot helping each otherso that the base culture impact of significant changesto the relationship between religion and humanity in Fak-Fak. It means that people are more open cultural ties looked atone anotheras brothers and sisters, whilereligion isoft entrapped in differentiating their limited his fellowco-religionists. Cultureof a three-stone hearth becomesa critique ofthe way and understand religion that tendexclusive of this era.
\end{abstract}

Keywords : Hearth, cooperation, humanity, religion, culture, conflict.

\begin{abstract}
Abstrak
Satu tungku tiga batu adalah bagian dari sistem kerjasama antar institusi di Kabupaten Fak-fak.Tetapi di dalamnya juga mengandung nilai-nilai kemanusiaan yang bermuara pada hubungan antar agama, tolong-menolong, saling mempedulikan dalam kesusahan dan kekurangan tanpa menjadikan agama sebagai sumber konflik ataupun alasan untuk tidak saling menolong sehingga basis budaya masyarakat membawa dampak perubahan yang signifikan bagi hubungan antar agama dan kemanusiaan di Fak-fak. Artinya bahwa ikatan budaya masyarakat lebih terbuka memandang satu dengan yang lain sebagai saudara, sementara agama justru sering terjebak dalam membedakan sesama saudaranya sebatas mereka yang seagama. Budaya satu tungku tiga batu menjadi kritik atas cara dan paham beragama yang eksklusif.
\end{abstract}

Kata Kunci : Tungku, kerjasama, kemanusiaan, agama, budaya, konflik. 


\section{PENGANTAR}

Setiap masyarakat memiliki adat istiadat yang di dalamnya jika disimak, maka terkandung nilai-nilai yang akan memberi dampak positif di dalam ruang lingkup bermasyarakat. Di dalam adat istiadat itu, terdapat norma atau pegangan yang mampu menjadikan setiap orang yang hidup di dalamnya membangun toleransi antar umat beragama. Hal ini disebabkan karena kemajemukan telah menjadi dasar bersama di dalam merajut adat-istiadat dimaksud.Kemajemukan atau pluralisme sudah ada sejak awalnya di terima sebagai sebuah prinsip bangsa ini. Bahwa kita harus mengakui kemajemukan adalah fakta dari masyarakat dan bangsa Indonesia. Menolak pluralisme atau kemajemukan sama saja dengan menolak prinsip bangsa ini. Bangsa yang menolak prinsipnya sendiri cepat atau lambat akan runtuh. Oleh karena itu, tidak boleh sampai terjadi ada kelompok masyarakat atau kelompok agama atau kelompok etnis atau kelompok budaya yangmerasa dipinggirkan atau terpinggirkan dalam kenyataan hidup bermasyarakat. Pluralisme atau kemajemukan seyogianya dipandang dan diterima sebagai kekayaan bangsa sekaligus merupakan Rahmat Tuhan yang besar bagi kita. $^{1}$

Selain itu pula, masyarakat dan kebudayaan lokal sering dikategorikan tipe masyarakat tradisional yang secara paradigmatis dipandang tak lagi memiliki relevansi maupun signifikansi dalam kompleksitas perkembangan masyarakat modern. Namun pada sisi lain, paradigma atau pandangan-hidup masyarakat lokal sering dimanfaatkan antara lain sebagai instrumen dalam komunikasi sosial dan politik modern. Dalam komunikasi politik praktis, sistem dan struktur serta simbol-simbol adat masyarakat lokal sering dieksploitasi untuk mencapai tujuan dan melindungi kepentingan serta akses kekuasaan. ${ }^{2}$ Kekhasan sosio-budaya masyarakat lokal Fakfak patut dikaji dan direnung ulang serta dimaknai.

Dalam realitas hidup masyarakat Fakfak- Papua Barat, di dalam bingkai budayanya tergambar akan khasanah pluralisme. Yang menjadi bingkai bersama dalam realitas hidup beragama dan bermasyarakat.Konsep tersebut di kenal dengan sebutan Satu Tungku Tiga Batu [Toromit War Istery].Konsep ini 
menjadi falsafah yang berhubungan dengan isu-isu keragaman dan dihubungkan dengan konteks sosial dan kultural.

Satu Tungku Tiga Batu, menjadi dasar di mana orang beragama membangun dialog bersama, saling menerima suku lain di luar orang Fakfak, serta dapat ditemukan bahwa di dalam satu marga [fam]terdapat tiga agama [Kristen Protestan, Katolik dan Islam] yang hidup bersama di dalam satu rumah. Yang mana tidak ada prasangka [prejudice], stigma ataupun perasaan fanatisme, karena mereka menyadari bahwa mereka berasal dari satu garis keturunan.Kesadaran akan hidup dalam keberagamaan dalam Satu Tungku Tiga Batu [Toromit War Istery]. Menjadikan orang Fakfak menerima siapapun untuk hidup bersama dan membangun kota Fakfak. Walaupun disadari saat ini terdapat agama dan denominasi gereja yang beragam, namun kesadaran akan semangat kekeluargaan tetap terjalin dan dirajut dalam spirit kemanusiaan. Itulah fakta pluralisme ${ }^{3}$ dalam keberagamaan di Fakfak.

Berdasarkan realita tersebut, maka tulisan ini akan menyoroti beberapa hal tentang Falsafah Hidup Orang Fakfak: Satu Tungku Tiga Batu [Toromit Warlstery] meliputi: Falsafah dan praktek Satu Tungku Tiga Batu, fakta Pluralisme: kesadaran akan Satu Tungku Tiga Batu dan Satu Tungku Tiga Batu Dialog Berbasis Kemanusiaan.

\section{FALSAFAH DAN PRAKTEK "satu tungku tiga batu"}

Salah satu kearifan budaya lokal yang dapat dijadikan rujukan pembelajaran bagaimana hidup bersama dibangun dan dipelihara terdapat dalam masyarakat Fakfak [Mbaham] yang terkenal dengan falsafahnya, yaitu: "Satu Tungku Tiga Batu", falsafah ini kerap memberikan penggambaran mengenai "Tiga Agama yang terdapat di Fakfak yaitu : Islam, Kristen Protestan dan Katolik" yang senantiasa hidup berdampingan satu dengan yang lain tanpa ada klaim-klaim ekslusivisme. Selain itu falsafah "Satu Tungku Tiga Batu” juga oleh masyarakat Mbaham diidentikan sebagai tiga pilar utama yakni "Adat, Agama dan Pemerintah” sehingga satu Tunggu Tiga Batu, dimengerti dalam kerangka pemahaman masyarakat setempat. Secara umum, Satu Tungku Tiga Batu, 
dimengerti sebagai suatu sistem kerjasama antar institusi. Misalnya di Maluku, dikenal dengan Tiga Batu Tungku, yaitu pemerintah negeri, gereja dan pendidikan. Ketiga unsur ini ada di dalam setiap negeri dan mengemban kerjasama sebagai suatu kesatuan, tanpa mereduksi makna dan fungsi tiap institusi di dalam masyarakat. ${ }^{4}$ Dengan demikian, sebelum mengkaji lebih jauh mengenai nilai-nilai sosial-religius yang terkandung dalam falsafah masyarakat Fakfak [Mbaham], maka kita perlu melakukan pendekatan rekonstruksi mengenai pengertian "Tungku". Menurut Kamus Besar Bahasa Indonesia edisi ketiga memberikan tiga arti mengenai Tungku: ${ }^{5}$

1. Batu dan sebagainya yang dipasang untuk perapian [dapur]; 2. Tempat tumpuan periuk dan sebagainya waktu memasak; 3. Dapur [perapian] terbuat dari baja dan sebagainya untuk menjerangkan atau memasak sesuatu; batu tungku.

Dari pengertian diatas maka kita memperoleh gambaran bahwa Tungku memiliki peranan yang sangat dominan dalam kehidupan manusia, secara khusus terlihat pada proses pengolahan makanan untuk konsumsi manusia. Tungku ini yang kemudian pada gilirannya dijadikan rujukan falsafah hidup masyarakat lokal Fakfak. Hal ini dikarenakan masyarakat Fakfak yang nota benenya masyarakat yang pluralistik, dan memiliki keadaban yang tinggi dengan adat istiadat, dan budaya yang khas gaya budaya peralihan.

Pranata dan pratata sosial yang dimiliki masyarakat Fakfak juga terbilang lebih maju, dan terbuka dibandingkan dengan suku-suku asli Papua lainnya. Solidaritas di dalam kehidupan bermasyarakat di Fakfakjugasangat tinggi.Tolongmenolong dan saling berbagi adalah gaya hidup orang Fakfak; mereka mempunyai slogan "Satu tungku Tiga batu", dalam bahasa asli "Toromit War Istery",yang mengandung filosofi "unity" atau kesatuan, kesehatian, dan saling menopang dalam berkarya.Dalam konteks pergaulan berbangsa dan bernegara, di Daerah Fakfak; pengertian slogan tersebut kemudian diperluas menjadi kesatuan gerak, dan tindakan bersama antara unsur Pemangku Adat, unsur Agama dan 
unsurPemerintah, dalam penatalayanan pembangunan Daerah Fakfak menuju kesejahteraan dan kemakmuran. ${ }^{6}$

Daerah Fakfak mengenal dan menerapkan sistem Pemerintahan Adat yang disebut"Petuanan". Istilah petuanan ini artinya daerah yang dipertuan oleh seorangraja, yang dalam bahasa asli disebut "Nady"atau "Naty". Sebuah Petuanan memiliki aparatur [pembantu raja], antara lain: Mayor [wakil raja], Hanggandy [sekretaris raja], Jijay [bendahara raja], Kapitan [kepala pemerintahan kampung dan dusun], dan Rong tua adalah Penasehat raja.

Sesungguhnya masyarakat asli Fakfak telah menerapkan sistem pemerintahan adat sejak abad permulaan sebelum Semenanjung ini dikunjungi bangsa asing dari Arab dan China pada abad ke 14.Sistem kerajaan di Fakfak mulai disempunakan dengan struktur yang lebih modern dan lengkap seperti yang diterapkan sekarang, ialah pada tahun 1534, ketika Kesultanan Tidore menjalin hubungan kerja sama pertahanan keamanan dan perdagangan dengan wali-wali negeri Semenanjung Onin AL-Mbaham. ${ }^{7}$

Toleransi kehidupan beragamadi Fakfak sangat harmonis.Mereka memiliki Falsafah yang dikenal dengan istilah "Agama Keluarga", atau dalam bahasa asli "Mbima Pkon Tery", kurang lebih pengertiannya adalah "Tiga tetapi sesungguhnya satu'.Mashab ini didasarkan pada pandangan bahwa semua agama adalah mulia, dan sama-sama punya satu saja tujuan yaitu menyembah Allah Yang Maha Esa, Tuhan pencipta alam semesta. Bahwa setiap agama sama mengajarkan kebajikan dan kebaikan yang menuntun kepada hakikat kebenaran Ilahi. Di jiwai oleh pandangan inilah, pada tahun 1500-an, ketika Agama Islam mulai disyiarkan di Jazirah ini, kemudian disusul oleh misi Katolik dan Protestan pada tahun 1800-an; maka orang Fakfak menerima ketiga agama tersebut [Islam, Katolik, dan Protestan] sebagai agama-agama milik Keluarga Besar Fakfak.Demikian dipraktekkan hingga sekarang, dimana masyarakat asli Fakfak, ada yang memeluk agama Islam, ada yang nasrani Katolik dan Protestan. Mashab ini ditanamkan dilestarikan dan menjadi suatu Model sistemToleransiBeragama yang sangat unik di Daerah ini, yakni toleransi hidup beragama yang dijiwai semangat kekerabatan dan kekeluargaan. Orang Fakfak sangat menjunjung tinggi 
pelaksanaan syariat semua agama yang ada. Mereka saling membantu dan saling menopang, misalnya dalam pembangunan rumah ibadah, juga dalam peringatan hari-hari besar keagamaan. ${ }^{8}$

Dalam kerangka inilah, maka sebagai makhluk berbudaya, manusia tidak terlepas dari budaya yang dianutnya.Suatu budaya memiliki nilai, nilai-nilai budaya itu ada dalam kehidupan sehari-hari dan berfungsi memberi arahan bagi tindakan manusia.Kebudayaan mesti dilihat sebagai kekayaan yang tidak boleh di tunggangbalikkan.Sebab kebudayaan pada galibnya memiliki tujuan yang mulia, yaitu mempertinggi derajat dan harkat [dignity] manusia.Kebudayaan yang dihasilkan secara sadar oleh manusia tidak bertujuan untuk menghadirkan eksesekses destruktif atau merusak, tetapi dari suatu budaya orang mengharapkan kemanusiaan sejati. ${ }^{9}$

\section{FAKTA PLURALISME: Kesadaran akan 'satu tungku tiga batu'}

Pada bagian ini ada dua hal yang dikedepankan, dua hal yaitu hidup berdampingan dengan agama lain dan upacara keagamaan keterlibatan masyarakat sebagai bagian dari pada kesadaran dan pemaknaan masyarakat Fakfak mengenai konsep Satu Tungku Tiga Batu.

\section{Hidup Berdampingan Dengan Agama Lain}

Secara umum, kajian tentang agama setidaknya terbagi ke dalam dua dimensi, yakni teologis dan sosiologis. Kajian agama dalam corak teologis berangkat dari adanya klaim tentang kebenaran mutlak ajaran suatu agama. Doktrin-doktrin keagamaan yang diyakini berasal dari Tuhan, kebenarannya juga diakui berada di luar jangkauan kemampuan pikiran manusia sehingga ia sematamata menjadi ajaran yang cukup diimani saja, pokoknya iman. Oleh karena itu, teologi sebagai suatu disiplin ilmu yang mengkaji agama, tidak pernah bisa bertanjak dari frame diatas, yaitu keimanan mutlak terhadap kebenaran ajaran agama yang diyakininya. Bahkan, misi sesungguhnya dari teologi adalah mempertahankan doktrin agama dengan menggunakan term-term yang rasionalfilosofis, sehingga tidaklah mengherankan jika ahli filsafat agama juga ikut ambil bagian dalam tugas ahli teologi ini. ${ }^{10}$ 
Berbeda dari dimensi teologis, dimensi sosiologis melihat agama sebagai salah satu institusi sosial, sebagai subsistem dari sistem sosial yang mempunyai fungsi sosial tertentu, misalnya sebagai salah satu pranata sosial, social institution. Karena posisinya sebagai sub sistem, maka eksistensi dan peran agama dalam suatu masyarakat tak ubahnya dengan posisi dan peran sub sistem lainnya, meskipun tetap mempunyai fungsi yang berbeda. Dengan kata lain, posisi agama dalam suatu masyarakat bersama-sama dengan subsistem lainnya [seperti subsistem ekonomi, politik, kebudayaan, dan lain-lain] mendukung terhadap eksistensi suatu masyarakat.Dalam konteks kajian sosiologis seperti ini, agama tidak dilihat berdasar apa dan bagaimana isi ajaran dan doktrin keyakinannya, melainkan bagaimana ajaran dan keyakinan agama itu dilakukan dan mewujud dalam perilaku pemeluknya dalam kehidupan sehari-hari.Agama hadir di dalam ruang sejarah dan sosiologis, sehingga di dalamnya setiap agama dituntut untuk dapat memperjuangkan kemanusiaan. Searah dengan hal dimaksud, menurut Joas Adiprasetya:

Semua agama dimuka bumi ini bersifat relatif. Manusia yang beragama adalah makhluk historis, yang dapat mengalami sesuatu dan hidup dalam suatu proses sejarah tertentu. Agama-agama dengan demikian menjadi sarana yang melaluinya manusia mengalami kehadiran Allah secara imanen. Semua agama memiliki karakter bersama, yaitu pengalaman akan penyataan Allah yang transenden dalam sejarah imanen. Dengan demikian agama dilihat sebagai suatu bentuk manifestasi dari Yang Absolute tidak bisa menjadi absolute karena keterikatan historisnya. ${ }^{11}$

Oleh sebab itu, setiap agama mengajarkan akan teologi persaudaraan. Akan tetapi nilai sebuah persaudaraan sangat mahal untuk diterapkan dalam realitas kemanusiaan.Konflik dan kekerasan yang ditampilkan oleh umat beragama dalam realitas hidupnya, menjadikan nilai persaudaraan semakin luntur.Pada hal di sadari, setiap agama memperjuangkan adanya kemanusiaan. 
Akan tetapi dalam realitas hidup masyarakat Fakfak, hidup berdampingan dengan agama lain bukanlah suatu masalah. Dalam masyarakat Fakfak tidak ada pertentangan mengenai agama, karena mereka ada dalam hubungan kekeluargaan yang sangat erat. Dan hal itu nampak kerukunan antar-umat beragama sangat dijaga dan dipelihara.

Hal ini mengindikasikan bahwa kerukunan adalah kehidupan bersama manusia yang diwarnai oleh suasana baik dan damai, saling menerima, meneguhkan, mendengarkan, menghargai, mengampuni, sehati dan seperasaan.Hidup rukun berarti tidak bertengkar, melainkan bersatu hati, sepakat dalam berpikir dan bertindak demi mewujudkan kesejahteraan bersama.Dalam kerukunan semua orang dapat hidup bersama tanpa kecurigaan, di mana tumbuh semangat dan sikap saling menghormati dan kesediaan untuk bekerja sama demi kepentingan bersama.

Sehubungan dengan kerukunan antar umat beragama, tahun 1985 Majelis Agung Wali Gereja Indonesia [MAWI] yang sejak tahun 1987 sesuai dengan ketentuan Hukum Gereja yang baru [1983] di ubah menjadi Konferensi Wali Gereja Indonesia, mengatakan:

"Kerukunan yang harus kita bangun itu bukan Sinkritesme atau oppurtunisme yang dangkal.Melainkan suatu sikap dewasa dalam iman, yang menghormati pandangan yang berbeda, juga dalam bidang agama dan menghargai serta mencintai orang yang tidak sepaham dengan kita.Sehubungan dengan itu, kita ingin membina bukan hanya toleransi antar golongan di dalam masyarakat Indonesia.Kita juga ingin membina sikap saling menghargai dalam suasana tenggang rasa. Dalam suasana itu kita mengusahakan dialog dan kerjasama dalam semangat persaudaraan. Dengan demikian, dapatlah ditingkatkan solidaritas nasional.Cakrawala manusia Indonesia tidak boleh dipersempit oleh kotak-kotak agama, rumpun, etnis, lapisan masyarakat dan sebagainya. ${ }^{12}$ 
Oleh sebab itu, kesadaran akan kerukunan antar umat beragama secara tidak langsung terbangun dalam hubungan kekerabatan yang sangat erat dalam kehidupan beragama masyarakat Fakfak suku Mbaham. Karena hubungan kekerabatan ini telah menjadi ikatan persaudaraan, yang tidak terkotak-kotak dalam masing-masing agama, melainkan hubungan kekeluargaan dimaksud nampak dalam sikap dan praktek adanya agama keluarga, dimana dalam satu keluarga ada beberapa agama yang dianut anggota-anggota keluarga tersebut. Hubungan antara anggota keluarga yang berbeda agama terjalin sangat baik. Berkumpul dan berbicara atau bertukar pikiran tentang agama masing-masing bukan menjadi suatu hal yang baru. Namun tetap saling menghormati dan tidak saling mempengaruhi, karena telah mengerti batas-batas yang telah ditetapkan dan menghargai perbedaan itu. Hal ini sudah menjadi komitmen dalam keluarga dan masyarakat. Pada sisi inilah praktek keberagamaan dalam Falsafah Satu Tungku Tioga Batu, nampak dalam agama dan etika kehidupan, sehingga agama dan etika dapat berperan terutama dalam menciptakan moral setiap komunitas. Etika dan agama dapat saling melengkapi terhadap tugas ini karena melalui etika ajaranajaran agama yang abstrak dapat didaratkan pada tataran kongkrit kehidupan setiap umat beragam. Sehingga individu dan kelompok yang berbeda agama menyadari bahwa dalam sebuah masyarakat terdapat sejumlah nilai kebenaran yang patut dilakukan oleh anggota komunitas dalam masyarakat itu.

Secara sosioligis agama dilihat sebagai suatu jenis sistem sosial tertentu yang dibuat oleh penganut-penganutnya. Leonard Swidler dan Paul Mojzes memperlihatkan bahwa oleh sebagian kelompok orang agama dilihat sebagai jalan hidup. Sedangkan kelompok yang lainnya meyakini agama sebagai peraturan yang mengatur relasi manusia dan hubungannya dengan hal yang bersifat Ketuhanan. ${ }^{13}$ Dalam pemikiran seperti ini agama tidak hanya berhubungan dengan realita yang sakral tetapi juga yang sekuler.

Bertolak dari perspektif diatas maka interplay etika dan agama sebagaimana dimaksudkan dapat dipahami dalam peran untuk menetapkan batas minimal yang mesti dimiliki bersama oleh semua umat beragama. Jadi sesungguhnya kita membutuhkan sebuah dasar bersama bagi tatanan hidup yang 
universal. Istilah Hans Kung yang kemudian diadopsi oleh dewan parlemen agama-agama terkait dengan masalah seputar dasar bersama ini adalah "Etik Global". ${ }^{14}$

Melihat kehidupan yang terjalin secara indah dalam falsafah Satu Tungku Tiga Batu, maka dampak negatif terlihat ketika perlakuan kepada adat istiadat menjadi lebih penting dari pada agama. Hal ini dapat dilihat ketika ada upacara adat, masyarakat memberikan persembahan kepada para leluhur setelah upacara usai barulah upacara keagamaan dibuat. Tak dapat disangkal bahwa kepercayaan kepada para leluhur hingga saat ini masih dijaga.

Dalam masyarakat Mbaham agama dan adat berjalan bersama. Kepercayaan kepada para leluhur masih terus dijaga, sehingga ketika ada upacara adat, orang-orang yang dituakan dalam masyarakat memanggil para leluhur untuk bersama-sama merayakan upacara adat yang dilakukan. Walaupun sudah percaya kepada Tuhan Yang Maha Esa. Kebiasaan atau penghormatan kepada para leluhur tetap dipertahankan.

\section{Upacara Keagamaan : Keterlibatan Masyarakat}

Ali Maksum, mengambarkan bahwa bangsa Indonesia adalah bangsa yang masyarakatnya sangat majemuk atau pluralis. Kemajemukan bangsa Indonesia dapat dilihat dari dua perspektif, yaitu: horizontal dan vertikal. ${ }^{15}$ Dalam perspektif horizontal, kemajemukan bangsa kita dapat dilihat dari perbedaan agama, etnis, bahasa daerah, geografis, pakaian, makanan, dan budayanya. Sementara, dalam perspektif vertikal, kemajemukan bangsa dapat dilihat dari perbedaan tingkat pendidikan, ekonomi, pemukiman, pekerjaan dan tingkat sosial budaya. ${ }^{16}$ Kemajemukan merupakan ciri khas bangsa Indonesia.Dari perspektif horizontal, maka hubungan antar agama menjadi hal terpenting dalam rangka menatalayani kehidupan bersama.Hubungan antar agama dalam masyarakat Fakfak menjadi spirit yang hidup dalam rangka saling bekerjasama, saling membantu dan menopang di antara umat beragama.

Hubungan yang harmonis antar agama pun dapat dilihat ketika melakukan upacara keagamaan - Natal yang dirayakan agama Kristen dan atau Idul Fitri 
yang dirayakan agama Islam, maupun upacara-upacara keagamaan lainnya. Selalu melibatkan satu sama lain, saling mengunjungi dengan semangat persaudaraan dan saling menghormati.Catatan cerita perjalanan dari Ari Sihasale dan Nia Zulkarnaen bersama Tim dalam rangka perjalanan mereka di Propinsi Papua dan Papua Barat dalam Alenia's Journey uncover Papua. Sewaktu mereka tiba di Distrik Kokas, Kabupaten Fakfak Papua Barat yang biasanya di tayangkan oleh salah satu TV Swasta, yaitu Metro TV.Dikisahkan oleh masyarakat kepada Tim, bahwa kesadaran beragama di sini sangat tinggi. Setiap orang hidup dan berproses secara bersama dengan agama lain. Misalnya, di saat bulan Puasa dan Idul Fitri umat Kristen menyediakan hidangan yang dipersiapkan dalam rangka kegiatan buka puasa bersama dengan orang Islam.Demikian pun pada saat Idul Fitri, orang Kristen menyediakan hidangan bagi saudara/i mereka yang sementara beribadah.

Hal ini memberi gambaran, bahwa masyarakat Fakfak memiliki kesadaran yang tinggi dalam rangka memahami dan memaknai setiap ajaran agama.Searah dengan hal ini menurut Ruhulessin, Agama-agama tidak bisa lagi berhadapan sebagai legitimasi politik dari kepentingan golongan-golongan agama yang berbeda.Sebaliknya agama-agama membangun kesadaran baru yang lebih memperhatikan soal-soal kemanusiaan.Pendekatan terhadap berbagai masalah kemasyarakatan lebih bersikap inklusif, yaitu memandang diri sendiri, agama sendiri selaku factor komplementer dari suatu kebulatan persoalan kemanusiaan yang bersifat komprehensif. ${ }^{17}$

Agama-agama secara internal harus berani melakukan kritik internal di dalam diri masing-masing.Kesadaran pluralism tidak saja dalam kerangka hubungan antar agama, tetapi terutama menjadi masalah di dalam agama sendiri. Pluralism mengandaikan adanya kesadaran bahwa batasan antara benar dan salah bukan lagi menjadi masalah antara agama saya dan agama orang lain, tetapi terutama di dalam agama sendiri. Kritik diri ini merupakan keharusan apabila diinginkan pergaulan antar umat beragama dapat berkembang ke arah membangun masyarakat yang bersatu, berkeadilan, berkedamaian dan menjunjung tegaknya harkat dan martabat manusia sekarang dan di masa yang akan datang. ${ }^{18}$ Selain itu juga, menurut Eka Darmaputera, adanya pluralitas agama, haruslah juga diterima 
tidak sebatas sebagai realitas sosial, tetapi juga dalam kerangka teologis (digumuli secara teologis tidak sekedar sosiologis). Sebagaimana dikatakan Eka Darmaputera:

"Perbedaan-perbedaan religius tidak dilihat semata-mata sebagai sesuatu yang tak terelakkan pada aras praktis, melainkan sebagai sesuatu yang bermakna dan pentingpada aras teologis.Kehadiran dan eksistensi mereka beragama lain dipahami tidak semata-mata sebagai realitas sosial, namun juga sebagai fenomena teologis.Dengan kata lain, itu harus dihadapi secara teologis pula". ${ }^{19}$

Gambaran lain yang merupakan bagian dari praktek pelaksanaan Satu Tungku Tiga Batu di Kabupaten Fakfak, yaitu dapat dilihat adalah pada saat pembangunantempat ibadah, mereka senantiasa saling membantu tanpa memandang latar belakang agama tertentu. Ketika membangun gereja, saudarasaudara dari Muslim turut membantu, begitupun sebaliknya ketika membangun Mesjid, saudara-saudari yang beragama Kristen pasti membantu bahkan ada yang masuk dalam kepanitiaan pembangunan. Bukan saja keterlibatan dalam upacara keagamaan dan pembangunan tempat ibadah yang menjadi sesuatu yang khas. Di Fakfak perkawinan antar agama pun menjadi sesuatu yang khas: keluarga dan marga digunung [sebagian besar beragama Kristen] memberikan anak atau saudara perempuan mereka untuk dinikahi oleh anak atau saudara laki-laki dari keluarga dan marga di pantai [sebagian besar beragama Islam], dan sebaliknya. Perkawinan demi perkawinan diantara keluarga dan marga tidak hendak ditabukan.Agaknya, lembaga perkawinan lintas agama ini berfungsi sebagai peneguh kohesi sosial kekerabatan mereka. ${ }^{20}$ Sehingga menurut Helweldery, lahirlah sebuah corak agama keluarga yang dimaksudkan adalah bahwa agama Islam dan Kristen bagi orang Fakfak dapat dianut dan dihidupi dalam satu keluarga.Dalam perbedaan keyakinan keagamaan, mereka tetap dapat hidup rukun dan damai sebagai satu keluarga.Mereka tetap dapat melaksanakan ritus dan ritual 
keagamaannya dengan baik. Saling mendorong dan mengingatkan setiap saudara untuk melaksanakan ajaran-ajaran agama dan ibadahnya secara baik.

Oleh sebab itu, konteks kehidupan sosio-kultural di Indonesia merupakan suatu ruang publik yang plural.Corak pluralitas masyarakat tampak dalam berbagai segi kehidupan masyarakat.Sebagai fakta masyarakat, pluralism harus diterima dan diakui bukan sebagai sikap taktis, tetapi sebagai sebuah kesadaran yang eksistnsial. Penolakan atau pengingkaran terhadap fakta pluralism sama saja merupakan pengingkaran terhadap eksistensi masyarakat atau eksistensi kemanusiaan.

\section{SATU TUNGKU TIGA BATU: Dialog Berbasis Kemanusiaan}

Setiap agama dituntut untuk memperjuangkan dan mampu mendorong serta menggairahkan sebuah kehidupan agama yang rukun, toleran, dialogis. Untuk itu, perlu di buka kesempatan bagi proses belajar lintas komunitas agama melalui program-program dialog, studi banding, ceramah-ceramah dengan melibatkan tokoh-tokoh lintas agama, pertukaran dosen lintas lembaga pendidikan yang berbasis agama.

Hal ini dipahami sebagai hal terpenting dalam rangka memahami dan memaknai 'sisi kemanusiaan' sebagai hal yang tetap diperjuangkan dan di promosikan di dalam dunia keagamaan. Sebab Menurut Berger, secara historis, agama merupakan salah satu bentuk legitimasi yang paling efektif. Agama merupakan semesta simbolik yang memberi makna pada kehidupan manusia dan yang memberikan penjelasan yang paling komprehensif tentang realitas seperti kematian, penderitaan, tragedi dan ketidakadilan. ${ }^{21}$

Dalam menjembatani beragam hal dimaksud, maka disadari dialog menjadi hal yang terpenting.Dialog itu merupakan komunikasi dua arah yang melaluinya para pelaku memandang betapa pentingnya perbedaan pandangan mengenai suatu pokok masalah. Karena itu mereka merasa perlu belajar lebih banyak kebenaran sekalipun datangnya dari orang lain. ${ }^{22}$ Sedangkan Knitter Memandang Dialog agama sebagai pertukaran pengalaman dan pemahaman di 
antara dua pihak atau lebih. Maksudnya, agar semua pihak bertumbuh dalam pengalaman dan pemahaman satu sama lain. ${ }^{23}$

Dialog yang baik adalah dialog yang dilakukan secara jujur, terbuka, kritis, saling menghormati dan menghargai perbedaan merupakan cara terbaik untuk membongkar kecurigaan, stigma serta membangun rasa saling percaya dan saling pengertian. Dialog tersebut lahir dalam budaya masyarakat, yang menyadari bahwa mereka tidak membutuhkan tempat yang mewah untuk saling bertukar pikiran. Tetapi dialog itu lahir di dalam realitas hidup mereka, lingkungan, tempat pekerjaan dan lingkungan keseharian mereka.

Hal ini memberi makna, bahwa dalam falsafah Satu Tungku Tiga Batu, maka orang Fakfak duduk dan bertukar pikiran tanpa memandang latar belakang mereka, tanpa rasa curiga terhadap dogma masing-masing agama. Mereka bertutur, berkisah tentang ruang kehidupan mereka, kesadaran bahwa mereka merupakan salah satu garis keturunan yang sama. Kesadaran ini melahirkan rasa keberagamaan yang muncul dalam budaya bermasyarakat yang dampaknya adalah sikap terbuka dan saling menerima agama lain, orang lain, suku lain untuk samasama memperjuangkan hidup dan kemanusiaan di Papua.

Kemanusiaan menjadi hal terpenting bagi siapapun dan agama manapun karena di situlah hakikat dan keterpanggilan setiap agama untuk bersuara dan berbicara di dalamnya.Kemanusiaan seringkali berusaha untuk di kebiri, karena rasa ekslusif dan fundamentalisme yang berlebihan.Hal ini memberi pertanda bahwa agama yang baik, maupun budaya yang baik adalah yang memperjuangkan kemanusiaan.Sebab manusia yang konkrit, yaitu orang-orang beriman dalam agama tertentu, dalam lingkungan budayanya dan harapannya.

\section{PENUTUP}

Menyadari akan konteks keberadaan masyarakat Papua yang kaya akan keragaman budaya, maka dituntut sikap untuk berbaur dan berproses dalam rangka memahami keberagaman yang ada sebagai suatu kekayaan yang tak ternilai harganya. Satu Tungku Tiga Batu adalah sebuah falsafah budaya yang dihasilkan sendiri oleh masyarakat Fakfak. Falsafah ini tidak hanya dimaknai 
dalam medan pemerintahan, akan tetapi lebih nampak dalam semangat keberagamaan.

Di mana di dalam satu keluarga terdapat dua bahkan tiga agama yang berbeda.Mereka hidup berbaur, berproses dan turut terlibat dalam pergumulan dan pekerjaan secara bersama.Tanpa memandang latar belakang agama tertentu.Kesadaran ini menjadi bagian terpenting dalam rangka memperjuangkan kemanusiaan. Oleh sebab itu, dapat dikatakan bahwa 'Satu Tungku Tiga Batu' telah menjadi spirit akan keragaman yang mempererat hubungan antar agama di Fakfak. Sehingga di dalamnya terkandung nilai-nilai kemanusiaan yang menerima, menghargai, dan menghormati perbedaan keragaman budaya, agama, etnis yang dan diakui sebagai pemberian Tuhan bagi manusia.

\section{Catatan akhir}

${ }^{1}$ Budaya adalah rangkaian kesatuah hal-hal dan peristiwa-peristiwa yang bersifat temporal dan ekstromatik yang bergantung pada simbolisasi. Secara spesifik dan kongkrit, budaya terdiri dari: Alat-alat, pakaian-pakaian, ornamen-ornamen, adat istiadat, institusi-institusi, kepercayaankepercayaan, ritual-ritual, permainan, karya seni, bahasa dan sebagainya. Baca: Leslie A. White, "The Evolution of Culture the Development of Civilization to the Fall of Rome", dalam Leassa A. William, Reader in Comparative Religion: An Anthropological Approach, New York: Harper\&Row Publisher, 1965. h. 12.

${ }^{2}$ Lihat laporan penelitian Oscar Salemink, Kisah Fundamentalisme Yang Telah Diceritakan Tiga Kali: Upaya Sosialis, Kapitalis, dan Protestan Untuk Mengubah Penduduk Dataran Tinggi Bagian Tengah Vietnam, dalam Renai, Jurnal Politik Lokal \& Sosial-Humaniora Tahun II Nomor 3-4 Juli-Oktober 2002, (Salatiga: Yayasan Percik), 82-114.

3 Paul F. Knitter membagi cara pandang Kristen terhadap agama-agama lain ke dalam tiga kelompok. Kelompok pertama adalah ekslusivisme, yang kedua adalah inklusifisme dan yang ketiga adalah pluralisme. Knitter, memperlihatkan bahwa masing-masing kelompok memiliki karakteristik sendiri-sendiri. Baca Paul F. Knitter, Satu Bumi Banyak Agama: Dialog MultiAgama dan Tanggung Jawab Global, (Terjemahan: N. Likumahua), Jakarta: BPK Gunung Mulia, 2003,h. 36.

${ }^{4}$ Elifas Tomix Maspaitella, Tiga Batu Tungku: Analisis Antropologis dan RefleksiTeologis Terhadap Kerjasama Antarinstitusi di Ema Pulau Ambon, Tesis pada Program Pascasarjana Magister Sosiologi Agama UKSW, 2002, h. 3

${ }^{5}$ Tim Penyusun, Kamus Besar Bahasa Indonesia, Jakarta: DEPDIKBUD, 1990.

${ }^{6}$ Nikodemus Rahajaan, Satu Tungku Tiga Batu, Makalah yang dipresentasikan pada Konsultasi Nasional Mahasiswa Teologi di Makasar yang dilakukan oleh PERSETIA, 2014, h. 3

${ }^{7}$ Willy Hegemur. "Prototype Rumah Tradisional Fakfak".DalamNikodemus Rahajaan, Satu Tungku Tiga Batu, h. 2

${ }^{8}$ Willy Hegemur. Ibid, h. 2

9. J W M. Bakker, Filsafat Kebudayaan: Sebuah Pengantar, Jakarta: BPK Gunung Mulia \& Yogyakarta: Kanisius, 1995, h. 15, 18

${ }^{10}$ Betty R. Scharf, Kajian Sosiologi Agama, Yogyakarta: Tiara Wacana, 1995, h. 2-3. 
11Joas Adiprasetya, Mencari Dasar Bersama: Etika Global dalam Kajian Postmodernisme dan Pluralisme Agama. Jakarta: BPK Gunung Mulia, 2002, h. 75.

${ }^{12}$ MAWI, Umat Katolik Indonesia Dalam Masyarakat Pancasila, Yogyakarta: Kanisius, 1985, h. 31; Lih. Mgr P C Mandagi, Dialog Antar Umat Beragama: Menuju Maluku Baru, Jurnal Ilmiah BENTARA: Berteologi Kontekstual Menjawab Tantangan Zaman, Edisi II Mei 2003, Ambon: GMKI Cab Ambon Komisariat Teologi UKIM, 2003, h. 3, 4

${ }^{13}$ Leonard Swidler and Paul Mojzes, The Study of Religion in age of Global DialogueI, Philadelphia: Temple University Press, 2000, h. 3.

${ }^{14}$ Secara tegas disebutkan oleh Kung bahwa yang dimaksud dengan Etika Global bukalah suatu ideologi global dari kesatuan agama yang ada dan bukan pula dominasi satu agama atas agama lain. Tetapi ynag dimaksudkan dengan Etika Global adalah sebuah konsensus fundamental tentang nilai yang mengikat, standar yang tidak bias diganggu, dan sikap personal.Hans Kung and Karl Josef K, Etik Global, Yogyakarta: Sisiphus bekerjasama dengan Pustaka Pelajar, 1999, h. 4

${ }^{15}$ Maksum Ali, Luluk Yunan Ruhendi, Paradigma Pendidikan Universal, Yogyakarta: Ircisod, 2004, h.190.

16Pelly Usman, dan Asih Menanti, Teori-teori Sosial Budaya, Jakarta: Dirjen Depdikbud, 1994, h.64.

${ }^{17}$ Rudy Rahabeat \& Abidin Wakanno [ed], Pluralisme Berwajah Humanis, Sketsa Pemikiran Dr. John Ruhulessin, Ambon: Lesmmu \& Yogyakarta: Galangpress, 2007, h. 44

${ }_{18}^{18}$ Rudy Rahabeat \& Abidin Wakanno [ed], Pluralisme Berwajah Humanis,... h.45

${ }^{19}$ Eka Darmaputera, Pergulatan Kehadiran Kristen Di Indonesia: Teks-teks terpilih Eka Darmaputera, Disunting oleh: Martin L. Sinaga dkk, Jakarta: BPK Gunung Mulia, 2001, h. 269

${ }^{20}$ R. Helweldery, Orasi Ilmiah: Agama Keluarga [Pemberi Inspirasi dan Perspektif Bagi Usaha Membangun Masyarakat Komunikatif - Masyarakat Multikultural], [STT GPI Papua Fakfak], 2007, h. 8-9.

${ }^{21}$ Peter L. Berger, Langit Suci: Agama Sebagai Realitas Sosial, Jakarta: LP3ES, 1991, h. 15

${ }^{22}$ Leonard Swidler and Paul Mojzes, The Study of Religion in age of Global DialogueI, Philadelphia: Temple University Press, 2000, h. 17

${ }^{23}$ Paul F. Knitter, Satu Bumi Banyak Agama: Dialog Multi-Agama dan Tanggung Jawab Global, (Terjemahan: N. Likumahua), Jakarta: BPK Gunung Mulia, 2003. h. 207

\section{DAFTAR PUSTAKA}

Adiprasetya Joas, 2002; Mencari Dasar Bersama: Etika Global dalam Kajian Postmodernisme dan Pluralisme Agama. Jakarta: BPK Gunung Mulia

Ali Maksum, Luluk Yunan Ruhendi,2004; Paradigma Pendidikan Universal, Yogyakarta: Ircisod

Bakker J W M., Filsafat Kebudayaan: Sebuah Pengantar, 1995; Jakarta: BPK Gunung Mulia \& Yogyakarta: Kanisius

Berger Peter L., 1991; Langit Suci: Agama Sebagai Realitas Sosial, Jakarta: LP3ES 
Darmaputera Eka, 2001; Pergulatan Kehadiran Kristen Di Indonesia: Teks-teks terpilih Eka Darmaputera, Disunting oleh: Martin L. Sinaga dkk, Jakarta: BPK Gunung Mulia

Helweldery R., 2007; Orasi Ilmiah: Agama Keluarga [Pemberi Inspirasi dan Perspektif Bagi Usaha Membangun Masyarakat Komunikatif - Masyarakat Multikultural], [STT GPI Papua Fakfak]

Knitter Paul F., 2003; Satu Bumi Banyak Agama: Dialog Multi-Agama dan Tanggung Jawab Global, (Terjemahan: N. Likumahua), Jakarta: BPK Gunung Mulia

Kung Hans and Karl Josef K, 1999; Etik Global, Yogyakarta: Sisiphus bekerjasama dengan Pustaka Pelajar, 1999

MAWI, 1985; Umat Katolik Indonesia Dalam Masyarakat Pancasila, Yogyakarta: Kanisius

Mandagi Mgr P C, 2003 Dialog Antar Umat Beragama: Menuju Maluku Baru, Jurnal Ilmiah BENTARA: Berteologi Kontekstual Menjawab Tantangan Zaman, Edisi II Mei, Ambon: GMKI Cab Ambon Komisariat Teologi UKIM

Maspaitella Elifas Tomix, 2002; Tiga Batu Tungku: Analisis Antropologis dan RefleksiTeologis Terhadap Kerjasama Antarinstitusi di Ema Pulau Ambon, Tesis pada Program Pascasarjana Magister Sosiologi Agama UKSW

Rahajaan Nikodemus, Satu Tungku Tiga Batu, Makalah yang dipresentasikan pada Konsultasi Nasional Mahasiswa Teologi di Makasar yang dilakukan oleh PERSETIA, 2014

Rahabeat Rudy \& Abidin Wakanno [ed], 2007; Pluralisme Berwajah Humanis, Sketsa Pemikiran Dr. John Ruhulessin, Ambon: Lesmmu \& Yogyakarta: Galangpress

Scharf Betty R., 1995; Kajian Sosiologi Agama, Yogyakarta: Tiara Wacana

Salemink Oscar, 2002;Kisah Fundamentalisme Yang Telah Diceritakan Tiga Kali: Upaya Sosialis, Kapitalis, dan Protestan Untuk Mengubah Penduduk Dataran Tinggi Bagian Tengah Vietnam, dalam Renai, Jurnal Politik Lokal 
\& Sosial-Humaniora Tahun II Nomor 3-4 Juli-Oktober Salatiga: Yayasan Percik

Swidler Leonard and Paul Mojzes, 2000; The Study of Religion in age of Global DialogueI, Philadelphia: Temple University Press

Usman Pelly, dan Asih Menanti, 1994; Teori-teori Sosial Budaya, Jakarta: Dirjen Depdikbud,

William Leassa A.,1965; Reader in Comparative Religion: An Anthropological Approach, New York: Harper\&Row Publisher 